\title{
Multiple sclerosis among United Kingdom-born children of immigrants from the Indian subcontinent, Africa and the West Indies
}

\author{
Marta Elian, Simon Nightingale, Geoffrey Dean
}

\begin{abstract}
Multiple sclerosis (MS) is very uncommon among ethnic Asians in the Indian subcontinent, among Asians and Africans resident in the New Commonwealth countries of Africa and in the West Indies. It is also very uncommor among those who have migrated to England from those countries. In contrast, the children born in the United Kingdom of Asian, African and West Indian immigrants have, in the age groups available for study, a high prevalence of MS of a similar order to that occurring in the general population of England.
\end{abstract}

Multiple sclerosis (MS) has long been reported to be very uncommon in Asia, in the new Commonwealth countries of Africa and in the West Indies. ${ }^{1-4}$ It is also extremely uncommon among ethnic Asians and African immigrants to England ${ }^{56}$ indicating that immigrants from low prevalence areas keep their low risk of developing MS when they migrate to high prevalence areas. The first big wave of immigrants from low prevalence countries to the United Kingdom (UK) was from the West Indies in the 1950's and their UK-born children reached the age when MS presents in the late 1970's and 1980's. These UK-born children of West Indian immigrants were the first group available for study to see if they had the low MS risk of their immigrant parents or the high risk that occurs in England. A study of West Indians resident in Greater London showed that they had a risk of developing MS similar to that estimated for the general population. $^{7}$

This report extends the Greater London study to include the West Midlands and also includes the UK-born children of ethnic Asian immigrants from the Indian subcontinent and ethnic African immigrants who are only now reaching the age when MS presents.

\section{Method}

In this study the following conventions are employed: Asia includes only the Indian subcontinent countries of India, Bangladesh and Pakistan; the West Indies include only the American New Commonwealth countries; Asian, African and West Indian refer to ethnic origin rather than country of birth, residence or nationality; the adjective "white" is used to distinguish people of European ancestry from ethnic Asians, Africans and West Indians.

\section{Patients}

Asians and Africans diagnosed as having MS can generally be detected in the hospital records by their characteristic names. However, West Indians usually have English, Scottish, Welsh or Irish names and are therefore less easily detected. Moreover, whereas finding immigrants is facilitated by the recording of their birthplace somewhere in their hospital records, it is more difficult to detect from the hospital records that a UKborn MS patient is of West Indian ethnic origin and a few of these patients may have been missed. We used the diagnostic index from the Hospital Activity Analysis Scheme and we asked and obtained the help of many informants particularly the consultants, registrars and other medical and secretarial staff of the neurological departments of the Greater London and West Midland hospitals. The Consultants' diagnoses of probable or possible MS were accepted. In addition some of the patients were tested for the presence of serum antibodies to human T-cell lymphoma/leukaemia virus (HTLV-1). Where necessary a copy of birth registration to verify the birthplace of the patient was obtained from the Office of Population Censuses and Surveys in London and the patients' general practitioners were asked to confirm the birthplace of the parents. The Medical Research Committees at the various hospitals gave us permission to study the patients' case records.

\section{Calculation of prevalence}

The populations at risk were taken from data on UK-born children by birthplace of their parents in the 1971 Census. ${ }^{8}$ Expected numbers of MS patients were derived from age and sex specific prevalence rates from the study in the London borough of Sutton, where the overall prevalence per 100000 for all categories of $\mathrm{MS}^{10}$ was 115 and for probable MS was 87 . For the 15-44 age range, the proportion of probable $M S$ to all categories of MS was $76 \%$ (ES Williams, personal communication) and we have calculated the Sutton rates for probable MS from the published age and sex specific prevalence rates of all MS. The standardised prevalence ratio (SPR) comparing observed with expected numbers and its $95 \%$ confidence limits $(95 \% \mathrm{CL})$ were calculated. ${ }^{11}$ In estimating the prevalence we have only included Asians, Africans or West 
Table 1 Probable MS in UK-born West Indians

\begin{tabular}{|c|c|c|c|c|c|c|c|c|c|c|c|c|}
\hline & Sex & $\begin{array}{l}\text { Date of } \\
\text { birth }\end{array}$ & $\begin{array}{l}\text { Age of } \\
\text { onset }\end{array}$ & $\begin{array}{l}\text { First } \\
\text { symptom }\end{array}$ & Sensory & Visual & $V E R$ & Brainstem & $U M N$ & $C S F$ & Parents & Residence \\
\hline $\begin{array}{l}1 \\
2 \\
3 \\
4 \\
5 \\
6 \\
7 \\
8 \\
9 \\
10 \\
11 \\
12 \\
13 \\
14 \\
15 \\
16 \\
17 \\
18 \\
19 \\
20^{3} \\
21 \\
22 \\
23 \\
24 \\
25 \\
26 \\
27^{s} \\
28\end{array}$ & $\begin{array}{l}F \\
F \\
M \\
F \\
M \\
F \\
F \\
F \\
F \\
F \\
M \\
F \\
F \\
M \\
F \\
M \\
F \\
M \\
F \\
F \\
F \\
F \\
F \\
F \\
M \\
M \\
F \\
M\end{array}$ & $\begin{array}{l}1959 \\
1963 \\
1958 \\
1961 \\
1960 \\
1956 \\
1958 \\
1961 \\
1961 \\
1966 \\
1964 \\
1958 \\
1962 \\
1963 \\
1955 \\
1957 \\
1961 \\
1955 \\
1967 \\
1966 \\
1961 \\
1959 \\
1963 \\
1959 \\
1961 \\
1961 \\
1967 \\
1963\end{array}$ & $\begin{array}{l}23 \\
14 \\
21 \\
21 \\
21 \\
24 \\
25 \\
21 \\
21 \\
17 \\
19 \\
18 \\
22 \\
18 \\
25 \\
22 \\
18 \\
27 \\
17 \\
21 \\
16 \\
25 \\
18 \\
20 \\
24 \\
18 \\
21 \\
22\end{array}$ & $\begin{array}{l}\text { Diplopia } \\
\text { Sensory } \\
\text { RBN } \\
\text { Sensory } \\
\text { RBN } \\
\text { RBN } \\
\text { Stem } \\
\text { RBN } \\
\text { Sensory } \\
\text { Sensory } \\
\text { Myelitis } \\
\text { Ataxia } \\
\text { Sensory } \\
\text { Ataxia } \\
\text { Ataxia } \\
\text { Stem } \\
\text { Sensory } \\
\text { Myelitis } \\
\text { Myelitis } \\
\text { Sensory } \\
\text { Stem } \\
\text { Sensory } \\
\text { Sensory } \\
\text { Hemiparesis } \\
\text { RBN } \\
\text { Myelitis } \\
\text { Sensory } \\
\text { Ataxia }\end{array}$ & $\begin{array}{l}+ \\
+ \\
+ \\
+ \\
+ \\
+ \\
+ \\
+ \\
+ \\
+ \\
+ \\
+ \\
+ \\
+ \\
+ \\
+ \\
+ \\
+ \\
+ \\
+ \\
+ \\
+ \\
+\end{array}$ & $\begin{array}{l}+ \\
+ \\
+ \\
+ \\
+ \\
+ \\
+ \\
+ \\
+ \\
+ \\
+ \\
+\end{array}$ & $\begin{array}{l}+ \\
+ \\
+ \\
+ \\
+ \\
+ \\
+ \\
+ \\
+ \\
+ \\
+ \\
+\end{array}$ & $\begin{array}{l}+ \\
+ \\
+ \\
+ \\
+ \\
+ \\
+ \\
+ \\
+ \\
+ \\
+ \\
+ \\
+ \\
+ \\
+ \\
+ \\
+ \\
+ \\
+ \\
+ \\
+ \\
+ \\
+ \\
+ \\
+\end{array}$ & $\begin{array}{l}+ \\
+ \\
+ \\
+ \\
+ \\
+ \\
+ \\
+ \\
+ \\
+ \\
+ \\
+ \\
+ \\
+ \\
+ \\
+ \\
+ \\
+ \\
+ \\
+ \\
+ \\
+ \\
+ \\
+\end{array}$ & $\begin{array}{l}+ \\
+ \\
+ \\
+ \\
+ \\
+ \\
+ \\
+ \\
+ \\
+ \\
+ \\
+ \\
+ \\
+ \\
+ \\
+ \\
+ \\
+ \\
+ \\
+ \\
+ \\
+ \\
+ \\
+ \\
+\end{array}$ & $\begin{array}{l}\text { WI-WI } \\
\text { WI-WI } \\
\text { WI-WI } \\
\text { WI-WI } \\
\text { WI-WI } \\
\text { WI-WI } \\
\text { WI-WI } \\
\text { WI-WI } \\
\text { WI-WI } \\
\text { WI-WI } \\
\text { WI-WI } \\
\text { WI-WI } \\
\text { WI-WI } \\
\text { WI-WI } \\
\text { WI-WI } \\
\text { WI-WI } \\
\text { WI-WI } \\
\text { WI-WI } \\
\text { WI-WI } \\
\text { WI-WI } \\
\text { WI-WI } \\
\text { WI-WI } \\
\text { WI-WI } \\
\text { WI-WI } \\
\text { WI-WI } \\
\text { WI-WI } \\
\text { WI-WI } \\
\text { WI-WI }\end{array}$ & $\begin{array}{l}\text { GL } \\
\text { GL } \\
\text { GL } \\
\text { GL } \\
\text { GL } \\
\text { GL } \\
\text { GL } \\
\text { GL } \\
\text { GL } \\
\text { GL } \\
\text { GL } \\
\text { GL } \\
\text { GL } \\
\text { GL } \\
\text { GL } \\
\text { GL } \\
\text { GL } \\
\text { GL } \\
\text { GL } \\
\text { GL } \\
\text { WM } \\
\text { WM } \\
W M \\
W M \\
W M \\
W M \\
\text { WM } \\
\text { WM }\end{array}$ \\
\hline
\end{tabular}

' = excluded from prevalence study (see text)

$+=$ presence of abnormality of somatosensory (Sensory), visual (Visual), brainstem or cerebellar (brainstem) and cortico-spinal (UMN) systems; abnormal visual evoked cortical potentials (VER); the presence of leucocyte pleocytosis, raised IgG or oligoclonal bands in the cerebrospinal fluid (CSF). RBN = Retrobulbar neuritis.

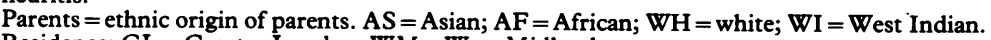

Residence: $\mathrm{GL}=$ Greater London; WM $=$ West Midlands

Indians with probable MS who were born in the United Kingdom and who on prevalence day (1 April 1986) were alive, living in Greater London or the West Midlands and whose first MS symptoms had occurred before that day. Since there is no available population at risk data for those born after 1971, MS cases were only included if they were over 15 years of age on our prevalence day. Except where explicitly stated, UK-born West Indian, Asian and African MS patients were only included if the ethnic origin and birthplace of both parents were the West Indies, Asia or Africa respectively.

\section{Results}

The date of birth, sex, age of onset, place of residence, birthplace of parents and some clinical details of patients with probable MS are shown in tables 1-4. Patients with possible MS are not included in the tables but are described in the text.

UK-born children of West Indian parents We have found 28 UK-born West Indians resident in Greater London and the West Midlands (table 1) with probable MS and this includes the five male and eleven female patients in Greater London described previously. ${ }^{7}$ There were also three female patients with possible MS in Greater London. All the patients resident in Greater London except for one were born in Greater London and all those resident in the West Midlands were born in the West Midlands. Table 2 shows six patients who had one white UK-born parent and one West Indian parent. The course of MS in UK-born West Indians in both Greater London and the West Midlands was unusually rapid and severe.

\section{UK-born children of Asian parents}

Thirteen UK-born Asian patients with probable MS were found in Greater London and the West Midlands (table 3). Three female UKborn Asians with probable MS had one Asian parent and one white UK-born parent (table 2). In addition in the West Midlands there were five UK-born Asians (four female; one male) with retrobulbar neuritis alone and three UKborn Asians (two female; one male) with

Table 2 Probable MS in UK-born patients of mixed parentage

\begin{tabular}{|c|c|c|c|c|c|c|c|c|c|c|c|c|}
\hline & $\operatorname{Sex}$ & $\begin{array}{l}\text { Date of } \\
\text { birth }\end{array}$ & $\begin{array}{l}\text { Age of } \\
\text { onset }\end{array}$ & $\begin{array}{l}\text { First } \\
\text { symptom }\end{array}$ & Sensory & Visual & $V E R$ & Brainstem & $U M N$ & $C S F$ & Parents & Residence \\
\hline $\begin{array}{l}1 \\
2 \\
3 \\
4 \\
5^{s} \\
6 \\
7 \\
8^{s} \\
9\end{array}$ & $\begin{array}{l}F \\
M \\
F \\
F \\
M \\
F \\
F \\
F \\
F\end{array}$ & $\begin{array}{l}1954 \\
1956 \\
1961 \\
1965 \\
1972 \\
1964 \\
1964 \\
1972 \\
1965\end{array}$ & $\begin{array}{l}20 \\
25 \\
15 \\
20 \\
12 \\
17 \\
17 \\
14 \\
19\end{array}$ & $\begin{array}{l}\text { Sensory } \\
\text { Ataxia } \\
\text { Sensory } \\
\text { Myelitis } \\
\text { RBN } \\
\text { Myelitis } \\
\text { Myelitis } \\
\text { Sensory } \\
\text { Myelitis }\end{array}$ & $\begin{array}{l}+ \\
+ \\
+ \\
+ \\
+ \\
+ \\
+ \\
+\end{array}$ & $\begin{array}{l}+ \\
+ \\
+ \\
+ \\
+ \\
+ \\
+\end{array}$ & $\begin{array}{l}+ \\
+ \\
+ \\
+\end{array}$ & $\begin{array}{l}+ \\
+ \\
+ \\
+ \\
+ \\
+ \\
+ \\
+ \\
+\end{array}$ & $\begin{array}{l}+ \\
+ \\
+ \\
+ \\
+ \\
+ \\
+ \\
+\end{array}$ & $\begin{array}{l}+ \\
+ \\
+ \\
+ \\
+\end{array}$ & $\begin{array}{l}\text { WI-WH } \\
\text { WI-WH } \\
\text { WI-WH } \\
\text { WI-WH } \\
\text { WI-WH } \\
\text { WI-WH } \\
\text { AS-WH } \\
\text { AS-WH } \\
\text { AS-WH }\end{array}$ & $\begin{array}{l}\text { GL } \\
\text { GL } \\
\mathbb{W M} \\
\mathbb{W M} \\
\mathbb{W M} \\
\mathbb{W M} \\
\mathbb{W} \\
\mathbb{W M} \\
\mathbb{W M} \\
\mathbb{W M}\end{array}$ \\
\hline
\end{tabular}

For legend see table 1 . 
Table 3 Probable MS in UK-born Asians

\begin{tabular}{|c|c|c|c|c|c|c|c|c|c|c|c|c|}
\hline & Sex & $\begin{array}{l}\text { Date of } \\
\text { birth }\end{array}$ & $\begin{array}{l}\text { Age of } \\
\text { onset }\end{array}$ & $\begin{array}{l}\text { First } \\
\text { symptom }\end{array}$ & Sensory & Visual & $V E R$ & Brainstem & UMN & $C S F$ & Parents & Residence \\
\hline $\begin{array}{l}1 \\
2 \\
3 \\
4 \\
5 \\
6 \\
7 \\
8 \\
9 \\
10 \\
11 \\
12^{3} \\
13\end{array}$ & $\begin{array}{l}\mathrm{F} \\
\mathbf{M} \\
\mathbf{M} \\
\mathbf{F} \\
\mathbf{F} \\
\mathbf{F} \\
\mathbf{F} \\
\mathbf{M} \\
\mathbf{F} \\
\mathbf{F} \\
\mathbf{F} \\
\mathbf{M} \\
\mathbf{F}\end{array}$ & $\begin{array}{l}1967 \\
1964 \\
1967 \\
1957 \\
1938 \\
1971 \\
1956 \\
1966 \\
1960 \\
1966 \\
1963 \\
1967 \\
1955\end{array}$ & $\begin{array}{r}13 \\
17 \\
14 \\
24 \\
23 \\
4 \\
16 \\
9 \\
18 \\
18 \\
13 \\
19 \\
24\end{array}$ & $\begin{array}{l}\text { RBN } \\
\text { Myelitis } \\
\text { Hemiparesis } \\
\text { Ataxia } \\
\text { Sensory } \\
\text { Ataxia } \\
\text { Sensory } \\
\text { Hemiparesis } \\
\text { RBN } \\
\text { RBN } \\
\text { Sensory } \\
\text { Sensory } \\
\text { Sensory }\end{array}$ & $\begin{array}{l}+ \\
+ \\
+ \\
+ \\
+ \\
+ \\
+ \\
+ \\
+ \\
+ \\
+ \\
+ \\
+\end{array}$ & $\begin{array}{l}+ \\
+ \\
+ \\
+ \\
+ \\
+ \\
+ \\
+ \\
+\end{array}$ & $\begin{array}{l}+ \\
+ \\
+ \\
+ \\
+ \\
+ \\
+ \\
+ \\
+ \\
+\end{array}$ & $\begin{array}{l}+ \\
+ \\
+ \\
+ \\
+ \\
+ \\
+ \\
+ \\
+ \\
+\end{array}$ & $\begin{array}{l}+ \\
+ \\
+ \\
+ \\
+ \\
+ \\
+ \\
+ \\
+ \\
+ \\
+ \\
+ \\
+\end{array}$ & $\begin{array}{l}+ \\
+ \\
+ \\
+ \\
+ \\
+ \\
+ \\
+ \\
+ \\
+ \\
+ \\
+ \\
+\end{array}$ & $\begin{array}{l}\text { AS-AS } \\
\text { AS-AS } \\
\text { AS-AS } \\
\text { AS-AS } \\
\text { AS-AS } \\
\text { AS-AS } \\
\text { AS-AS } \\
\text { AS-AS } \\
\text { AS-AS } \\
\text { AS-AS } \\
\text { AS-AS } \\
\text { AS-AS } \\
\text { AS-AS }\end{array}$ & $\begin{array}{l}\text { GL } \\
\text { GL } \\
\text { GL } \\
\text { GL } \\
\text { GL } \\
\text { GL } \\
\text { WM } \\
\text { WM } \\
\text { WM } \\
\text { WM } \\
\text { WM } \\
\text { WM } \\
\text { WM }\end{array}$ \\
\hline
\end{tabular}

For legend see table 1.

transverse myelitis alone and one female with a transient brainstem disturbance. Of these nine possible MS patients, all their parents were Asia-born Asians except two patients who each had one parent born in East Africa.

The age of the first symptom of probable or possible MS in UK-born Asians (including those with mixed Asian/white parentage and those with a parent born in Africa) was strikingly young (mean age 16.4 years, standard deviation 4.72 ) with 11 of the 28 having their first symptom before the age of 15 ; one at 4 , one at 9 , one at 10 , two at 12 , four at 13 and two at 14 years of age.

UK-born children of parents born in Africa Table 4 shows four probable MS patients with both parents born in Africa. Two of these were UK-born Africans with parents from West Africa: the other two were UK-born Asians with parents from East Africa. In addition, we found a male UK-born African resident in Greater London with possible MS with parents from West Africa.

\section{Prevalence rates}

The populations at risk, the numbers of UKborn West Indian and Asian patients with probable $M S$ and the MS prevalence rates from the Sutton study ${ }^{9}$ are shown in tables 5 and 6. Some patients in tables 1 to 4 are excluded from the observed numbers in tables 5 and 6 as the onset of their MS was after the prevalence day (patients 20 and 27 in table 1 ; patient 12 in table 3 ) or because they were under 15 years of age on prevalence day (patients 5 and 8 in table 2). Of the patients included in the prevalence estimations, the 13 that were tested were seronegative for HTLV-1.

The expected numbers of MS cases in UKborn West Indians and Asians estimated from the Sutton study data are also shown from which are calculated a standard prevalence ratio (SPR) for UK-born West Indians in Greater London and the West Midlands together of $0.75(95 \%$ CL $0.49-1 \cdot 10)$ and for Asians of 1.10 (95\% CL 0.57-1.92).

The Asian or African MS patients whose parents were born in Africa are considered together as the 1971 Census does not distinguish between Asian, African or white UKborn children of Africa-born parents. The SPR for this small cohort is 1.52 (95\% confidence limits $0.42-3.91$ ) and would be higher if the UK-born children of returning white expatriates could be excluded from the population at risk. The proportion of immigrants from Africa in the years $1984-6$ that were white, African or Asian was 21, 21 and $58 \%$ respectively (Office of Population Censuses and Surveys, London; personal communication) and if similar rates apply to the UK-born children of the Africa-born parents the SPR will be proportionately greater.

Five UK-born probable MS patients with one West Indies-born parent and one white UK-born parent were eligible for inclusion on the prevalence day (Greater London and West Midlands combined). There are no precise data available for the population at risk for this group. However, using the 1971 Census data of UK-born individuals with one parent born in the New Commonwealth (America) and the other born outside the New Commonwealth, the expected number of MS patients was $11 \cdot 2$, based on the Sutton study prevalence rates. For this small group the SPR was $0.43(95 \% \mathrm{CL}$ 0.14-1.03). Similar calculations for the two UK-born probable MS patients resident in the West Midlands with one parent born in India or Pakistan and one white UK-born parent gave an SPR of $0.06(95 \%$ CL 0.008-0.21) for Greater London and the West Midlands combined or $0.42(95 \%$ CL $0.05-1.53)$ for the West Midlands alone.

Table 4 Probable MS in UK-born children of parents born in Africa

\begin{tabular}{|c|c|c|c|c|c|c|c|c|c|c|c|c|}
\hline & Sex & $\begin{array}{l}\text { Date of } \\
\text { birth }\end{array}$ & $\begin{array}{l}\text { Age of } \\
\text { onset }\end{array}$ & $\begin{array}{l}\text { First } \\
\text { symptom }\end{array}$ & Sensory & Visual & $V E R$ & Brainstem & $U M N$ & $C S F$ & Parents & Residence \\
\hline $\begin{array}{l}1 \\
2 \\
3 \\
4\end{array}$ & $\begin{array}{l}\mathbf{M} \\
\mathbf{F} \\
\mathbf{F} \\
\mathbf{F}\end{array}$ & $\begin{array}{l}1961 \\
1955 \\
1965 \\
1963\end{array}$ & $\begin{array}{l}18 \\
18 \\
17 \\
21\end{array}$ & $\begin{array}{l}\text { Myelitis } \\
\text { Stem } \\
\text { Stem } \\
\text { Myelitis }\end{array}$ & $\begin{array}{l}+ \\
+ \\
+ \\
+\end{array}$ & + & $\begin{array}{l}+ \\
+\end{array}$ & $\begin{array}{l}+ \\
+ \\
+ \\
+\end{array}$ & $\begin{array}{l}+ \\
+ \\
+ \\
+\end{array}$ & $\begin{array}{l}+ \\
+ \\
+ \\
+\end{array}$ & $\begin{array}{l}\text { AF-AF } \\
\text { AF-AF } \\
\text { AS-AS } \\
\text { AS-AS }\end{array}$ & $\begin{array}{l}\text { GL } \\
\text { GL } \\
\text { GL } \\
\text { GL }\end{array}$ \\
\hline
\end{tabular}

For legend see table 1 . 
Table 5 UK-born West Indians with probable MS

\begin{tabular}{|c|c|c|c|c|c|c|c|c|c|c|c|c|}
\hline \multirow[b]{2}{*}{ Age } & \multirow[b]{2}{*}{ Residence } & \multicolumn{3}{|c|}{ Pop at Risk } & \multicolumn{3}{|c|}{ MS Cases } & \multicolumn{3}{|c|}{ Sutton Rate } & \multicolumn{2}{|c|}{ Exp MS Cases } \\
\hline & & $M$ & $F$ & & $M$ & & $F$ & $M$ & $F$ & & $M$ & $F$ \\
\hline $15-19$ & $\begin{array}{l}\text { GL } \\
\text { WM } \\
\text { Total }\end{array}$ & $\begin{array}{r}15315 \\
4615 \\
19930\end{array}$ & $\begin{array}{r}15195 \\
4630 \\
19825\end{array}$ & & $\begin{array}{l}1 \\
0 \\
1\end{array}$ & & $\begin{array}{l}3 \\
0 \\
3\end{array}$ & $18 \cdot 8$ & $12 \cdot 1$ & & 3.75 & $2 \cdot 40$ \\
\hline $20-24$ & $\begin{array}{l}\text { GL } \\
\text { WM } \\
\text { Total }\end{array}$ & $\begin{array}{r}19055 \\
6295 \\
25350\end{array}$ & $\begin{array}{r}18885 \\
6230 \\
25115\end{array}$ & & $\begin{array}{l}3 \\
3 \\
6\end{array}$ & & $\begin{array}{l}4 \\
2 \\
6\end{array}$ & $18 \cdot 8$ & $12 \cdot 1$ & & $4 \cdot 76$ & 3.04 \\
\hline $25-29$ & $\begin{array}{l}\text { GL } \\
\text { WM } \\
\text { Total }\end{array}$ & $\begin{array}{l}7330 \\
2580 \\
9910\end{array}$ & $\begin{array}{l}7320 \\
2465 \\
9785\end{array}$ & & $\begin{array}{l}2 \\
0 \\
2\end{array}$ & & $\begin{array}{l}5 \\
2 \\
7\end{array}$ & $49 \cdot 9$ & $134 \cdot 8$ & & 4.95 & $13 \cdot 19$ \\
\hline $30-34$ & $\begin{array}{l}\text { GL } \\
\text { WM } \\
\text { Total }\end{array}$ & $\begin{array}{l}700 \\
170 \\
870\end{array}$ & $\begin{array}{l}735 \\
195 \\
930\end{array}$ & & $\begin{array}{l}0 \\
0 \\
0\end{array}$ & & $\begin{array}{l}1 \\
0 \\
1\end{array}$ & 49.9 & 134.8 & & 0.43 & $1 \cdot 25$ \\
\hline$>35$ & $\begin{array}{l}\text { GL } \\
\text { WM } \\
\text { Total }\end{array}$ & $\begin{array}{r}225 \\
70 \\
295\end{array}$ & $\begin{array}{r}275 \\
90 \\
365\end{array}$ & & $\begin{array}{l}0 \\
0 \\
0\end{array}$ & & $\begin{array}{l}0 \\
0 \\
0\end{array}$ & $103 \cdot 1^{\star}$ & $183 \cdot 7^{\star}$ & & $0.30^{\star}$ & $0 \cdot 67^{\star}$ \\
\hline & TOTALS & & Observed & $\begin{array}{l}= \\
=\end{array}$ & 9 & $\begin{array}{r}+ \\
26\end{array}$ & 17 & & Expected & $\begin{array}{l}= \\
=\end{array}$ & $\underset{34 \cdot 74}{14 \cdot 19}+$ & $20 \cdot 55$ \\
\hline
\end{tabular}

Age on 1st April 1986. GL = Greater London. WM=West Midlands.

Population at risk is derived from the 1971 Census data on UK-born children of immigrants from the New Commonwealth (America). "Exp MS Cases" are the expected number of Probable MS cases in UK-born West Indians based on the "Sutton rate". Rate is per 100000 .

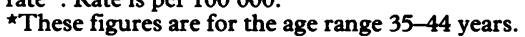

\section{Discussion}

Our results show that the UK-born children of Asian, West Indian and African immigrants have a high prevalence of $M S$ in the age groups available for study, of a similar order to that reported in the London borough of Sutton. This study is based on relatively small numbers of MS patients and is liable to several sources of variation or bias, in particular errors in case finding, in estimating the population at risk and in calculating the age and sex specific expected numbers. The statistical effect of variation in small numbers has already been considered in estimating the confidence limits of the SPRs. Misdiagnosis of MS in the patients in this study is very unlikely as all patients with probable MS showed typical clinical features. The negative HTLV-1 serology, clinical presentation and subsequent course indicate that we have not included patients with tropical spastic paraparesis.

On the other hand it is likely that we failed to pick up every case of MS in UK-born Asians, Africans and especially among West Indians with English names. On perusing some of the patients' case notes, there was sometimes an apparent reluctance to diagnose $M S$ in view of their ethnic origin and if this attitude is widespread then we may be underestimating the prevalence of MS in Asians and West Indians. The observation that MS in UK-born Asians has an unusually early onset may be due to a racial predisposition to an atypical presentation or alternatively the high prevalence in the young could reflect a high overall prevalence that will become more apparent as the UKborn Asian cohort ages. If the latter explanation is correct, the overall prevalence in UKborn Asians may eventually be greater than in the white UK-born population. Similarly our finding that MS in UK-born West Indians has a particularly severe course could either be due to a racial predisposition or due to the fact that we are only picking up the severe cases and

Table 6 UK-born Asians with probable MS

\begin{tabular}{|c|c|c|c|c|c|c|c|c|c|c|c|c|}
\hline \multirow[b]{2}{*}{ Age } & \multirow[b]{2}{*}{ Residence } & \multicolumn{2}{|c|}{ Pop at Risk } & & \multicolumn{3}{|c|}{ MS Cases } & \multicolumn{3}{|c|}{ Sutton Rate } & \multicolumn{2}{|c|}{ Exp MS Cases } \\
\hline & & $M$ & $F$ & & $M$ & & $F$ & $M$ & $F$ & & $\bar{M}$ & $F$ \\
\hline $15-19$ & $\begin{array}{l}\text { GL } \\
\text { WM } \\
\text { Total }\end{array}$ & $\begin{array}{r}7180 \\
7840 \\
15020\end{array}$ & $\begin{array}{r}6955 \\
7580 \\
14535\end{array}$ & & $\begin{array}{l}1 \\
1 \\
2\end{array}$ & & $\begin{array}{l}2 \\
1 \\
3\end{array}$ & $18 \cdot 8$ & $12 \cdot 1$ & & $2 \cdot 82$ & $1 \cdot 76$ \\
\hline $20-24$ & $\begin{array}{l}\text { GL } \\
\text { WM } \\
\text { Total }\end{array}$ & $\begin{array}{l}2985 \\
2890 \\
5875\end{array}$ & $\begin{array}{l}6955 \\
2790 \\
6630\end{array}$ & & $\begin{array}{l}1 \\
0 \\
1\end{array}$ & & $\begin{array}{l}0 \\
1 \\
1\end{array}$ & $18 \cdot 8$ & $12 \cdot 1$ & & $1 \cdot 10$ & 0.80 \\
\hline $25-29$ & $\begin{array}{l}\text { GL } \\
\text { WM } \\
\text { Total }\end{array}$ & $\begin{array}{r}850 \\
575 \\
1425\end{array}$ & $\begin{array}{r}855 \\
520 \\
1375\end{array}$ & & $\begin{array}{l}0 \\
0 \\
0\end{array}$ & & $\begin{array}{l}1 \\
2 \\
3\end{array}$ & $49 \cdot 9$ & 134.8 & & 0.71 & 1.85 \\
\hline $30-35$ & $\begin{array}{l}\text { GL } \\
\text { WM } \\
\text { Total }\end{array}$ & $\begin{array}{r}390 \\
90 \\
480\end{array}$ & $\begin{array}{r}370 \\
55 \\
425\end{array}$ & & $\begin{array}{l}0 \\
0 \\
0\end{array}$ & & $\begin{array}{l}0 \\
1 \\
1\end{array}$ & $49 \cdot 9$ & 134.8 & & 0.24 & 0.57 \\
\hline$>35$ & $\begin{array}{l}\text { GL } \\
\text { WM } \\
\text { Total }\end{array}$ & $\begin{array}{r}325 \\
45 \\
370\end{array}$ & $\begin{array}{r}325 \\
65 \\
390\end{array}$ & & $\begin{array}{l}0 \\
0 \\
0\end{array}$ & & $\begin{array}{l}1 \\
0 \\
1\end{array}$ & $103 \cdot 1^{\star}$ & $183 \cdot 7^{\star}$ & & $0.38^{\star}$ & $0.72^{\star}$ \\
\hline & TOTALS & & Observed & $=$ & 3 & $\stackrel{+}{12}$ & 9 & & Expected & $\begin{array}{l}= \\
=\end{array}$ & $5.25 \underset{10.95}{+}$ & $5 \cdot 70$ \\
\hline
\end{tabular}

Population at risk is derived from the 1971 Census data on UK-born children of immigrants from India and Pakistan "Exp MS Cases" are the expected number of probable MS cases in UK-born Asians based on the "Sutton rate". For other details see table 5 . 
missing the milder ones. If the latter explanation is correct, then we have underestimated the prevalence in UK-born West Indians.

The last census of UK-born children by birthplace of parents took place in 1971 and has been used to calculate the population at risk. This ignores movement in and out of Greater London and the West Midlands and also deaths in the population since 1971 , but since all our MS patients except one were born where they are now residing in Greater London or the West Midlands, there has probably been little overall change in the population since 1971 . Moreover, our use of the 1971 census data is shown ${ }^{7}$ to be fairly accurate when compared with the Head of Household Survey at the 1981 Census $^{12}$ and the small sample 1981 Labour Force Survey. ${ }^{13}$ Many couples of European ancestry who were born in Asia or the West Indies returned to the UK and their children born in this country are unavoidably included in the population at risk derived from the 1971 Census. Since our prevalence study has only included ethnic Asian and West Indian MS patients, the inclusion of these white children in the population at risk will result in an overestimation of the expected number of MS patients. Overestimation of expected numbers may also have occurred if some UK-born Asians and West Indians have died or migrated to their parents' country of origin.

At present there are no available age and sex specific MS prevalence data for the general population of either Greater London or the West Midlands with which to compare the prevalence rates of our UK-born Asian and West Indian MS patients. The recent prevalence study in the London borough of Sutton which we have used to calculate expected numbers in the populations at risk found an unexpectedly high overall prevalence of MS. If Sutton is not representative of Greater London or the West Midlands then we may be overestimating the expected numbers. Another reason why the high Sutton prevalence rates may bias our estimation of expected numbers concerns differences in methods of case finding. Whereas the Sutton rates were obtained by comprehensive survey of a relatively small population of 169600 using a wide variety of methods including contact with all general practitioners, our search for a small number of UK-born West Indians and Asians was from a total population of approximately $11700000^{12}$ (Greater London and West Midlands combined) using necessarily less intensive methods. It is well recognised that the prevalence rates from studies of small communities tend to be higher than less intensive surveys of large populations, for example in Sicily..$^{14} \mathrm{We}$ believe that all the sources of bias (that is, in case finding, in estimation of the population at risk and in calculation of expected numbers) described above would, if anything, have led us to underestimate the prevalence of MS in UKborn West Indians and Asians.

For those of mixed parentage (for example, UK-born individuals with one Asian Asiaborn parent and one white UK-born parent) factors additional to those detailed above may result in underestimation of the prevalence of MS. The population at risk for those of mixed parentage is relatively older than for those of full parentage. For example, the percentage of people over 30 years of age for West Indians of full and mixed parentage were $2.2 \%$ and $16.1 \%$ respectively and for Asians of full and mixed parentage were $4.2 \%$ and $47.0 \%$ respectively. These differences in age structure result in a relatively high expected number of MS cases in those of mixed parentage, yet the observed numbers were small and the SPR's were lower than for those of full Asian or West Indian parentage.

We believe that the likely explanations for this are firstly that the individuals of mixed parentage were not recognised as such by the doctors and were therefore missed. Secondly, many of the UK-born Asian individuals of mixed parentage will be children of UK-born fathers working in Asia and Asian mothers who both came to this country before or at Indian independence. Such individuals will have English sounding surnames which would obviate one of our main methods of detecting Asian MS cases. Thirdly, it seems likely that some of the UK-born individuals of mixed parentage that make up the population at risk derived from the 1971 census had both parents of European ancestry though one parent had been born in Asia or the West Indies. Since our study does not include white MS patients, this bias will result in an overestimation of the expected number of cases. Fourthly, the population at risk for those of mixed Asian/ white parentage derived from the 1971 Census may be an overestimation, since it includes not only individuals with one Asian parent and one white UK-born parent but also individuals with one Asian parent and one parent born anywhere outside the New Commonwealth. The same applies for the population at risk for those of mixed West Indian/white parentage.

The greater prevalence in UK-born Asians than in UK-born West Indians may be due firstly to the greater ease of identifying Asians' names; secondly to the fact that we may be only picking up the more severe West Indians; and thirdly to the earlier age of onset of MS in the Asians. Although the results show that UKborn whites, Asians and West Indians have a similar prevalence, the wide confidence limits allow the possibility that prevalence may also be influenced by ethnic origin through a genetic influence.

Although a genetic influence ${ }^{16}$ in the aetiology of $\mathrm{MS}$ is indicated by the greater concordance in monozygotic than dizygotic twins, by HLA studies and by the different prevalences in different racial groups in the USA, the change from the very low MS risk of people in Asia, Africa and the West Indies to the high risk among their UK-born children demonstrates that place of birth and residence in early life are of great importance.

We thank all the many people who have assisted us with this study, in particular the neurologists, senior medical officers and their secretaries at the hospitals in Greater London and in the West Midlands. We also thank the staff who provided us with computer printouts of patients diagnosed with MS from the four 
Thames and the West Midlands Regional Health Authorities, and the staff of the Office of Population Censuses and Surveys who provided us with the populations at risk and copies of the who provided us with the populations at risk and copies of the
birth notifications of the UK-born patients. Miss Hilda birth notifications of the UK-born patients. Miss Hilda
McLoughlin assisted with the preparation of the tables and the paper. This study was supported by a grant from the Multiple Sclerosis Society of Great Britain and Northern Ireland.

1 Cruickshank EK, Montgomery RD. Multiple sclerosis in Jamaica. West Indian Med J 1961;10:211.

2 Spillane JD. Tropical neurology. Oxford: Oxford University Press, 1983.

3 Matthews WB, Acheson ED, Batchelor JR, Weller RO McAlpines multiple sclerosis. Edinburgh: Churchil McAlpines multiple
Livingstone, 1985.

4 Dean G. Annual incidence, prevalence and mortality of multiple sclerosis in white South African-born and in white immigrants to South Africa. Br Med J 1967;2: 724-30.

5 Dean G, McLoughlin H, Brady R, Adelstein AM, TallettWilliams J. Multiple sclerosis among immigrants in Greater London. Br Med J 1976;1:861-4.

6 Dean G, Brady R, McLoughlin H, Elian M, Adelstein AM.
Motor neurone disease and multiple sclerosis among immigrants to Britain. Br J Prev Soc Med 1977;31:141-7. 7 Elian M, Dean G. Multiple sclerosis among the United Kingdom-born children of immigrants from the West Indies. J Neurol Neurosurg Psychiat 1987;50:327-32.

8 Office Population Censuses and Surveys. Country of birth Great Britain, Census 1971. London: HMSO, 1974.

9 Williams ES, McKeran RD. Prevalence of multiple sclerosis in a South London borough. Br Med J 1986;2:237-9.

10 Allison RS, Millar JHD. Prevalence of disseminated sclerosis in Northern Ireland. Ulster Med J 1954;23:5-27.

11 Breslow NE, Day NE. Statistical methods in cancer research, Vol 2. The analysis of cohort studies. Oxford: Oxford University Press, 1988.

12 Office Population Censuses and Surveys. The country of birth, Great Britain, Census 1981. London: HMSO, 1983. 13 Office Population Censuses and Surveys. Labour force survey, 1981. London: HMSO, 1982.

14 Societa Italiana di Neurologia. XIX Congresso Nazionale, Genova, 1975.

15 Dean G, Grimaldi G, Kelly R, Karhausen L. Multiple sclerosis in southern Europe. I: Prevalence in Sicily in 1975. J Epidemiol Community Health 1979;33:107-10.

16 Compston A. Genetic factors in the aetiology of multiple sclerosis. In: McDonald WI, Silberberg DH, eds. 